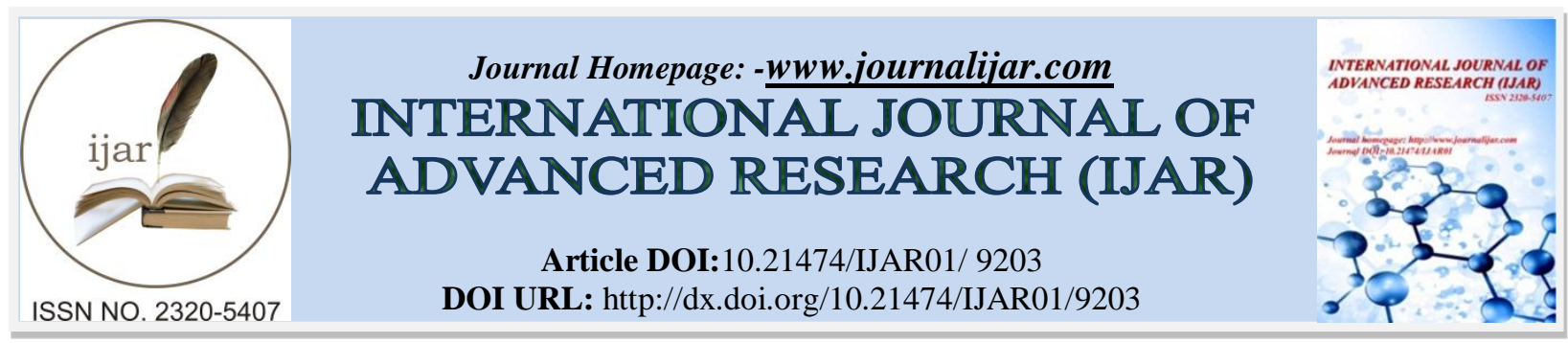

RESEARCH ARTICLE

\title{
TEACHERS' BELIEFS AND PRACTICES IN TEACHING READING: A SOCIO-COGNITIVE PERSPECTIVE.
}

\author{
Lanjar Utami ${ }^{1}$, Joko Nurkamto ${ }^{2}$, Nunuk Suryani ${ }^{3}$ and Gunarhadi ${ }^{4}$.
}

1. Department of Education Science, Universitas Sebelas Maret, Surakarta, Central Java, Indonesia.

2. Department of English Education, Universitas Sebelas Maret, Surakarta, Central Java, Indonesia.

3. Department of History Education, Universitas Sebelas Maret, Surakarta, Central Java, Indonesia.

4. Department of Special Education, Universitas Sebelas Maret, Surakarta, Central Java, Indonesia.

\section{Manuscript Info}

[.......................

Manuscript History

Received: 04 April 2019

Final Accepted: 06 May 2019

Published: June 2019

Key words:-

Beliefs, practices, teaching reading, socio-cognitive perspective.

\section{Abstract}

Teachers' beliefs are thought to have a great influence on their classroom practices. Due to the great influence, teachers' beliefs and practices in teaching reading have been recently gaining increased research momentum. This case study examined the teachers' beliefs and practices in teaching reading viewed from a socio-cognitive perspective. To achieve the stated purposes, three experienced Indonesian EFL teachers at Islamic Secondary School Madrasah Aliyah were interviewed and observed in their classrooms. The collected data were analyzed using constant comparative method. The findings of the study showed that what the teachers believed was articulated in what they practiced in the classroom. However, there were still some deviances that appeared in the classroom. It can be concluded that the teachers' practices were not always consistent with their beliefs. They were affected by some factors both from teachers and students.

Copy Right, IJAR, 2019,. All rights reserved.

\section{Introduction:-}

Teachers' beliefs are thought to have a great influence on their classroom practices. Due to the great influence, teachers' beliefs and practices in teaching reading have been recently gaining increased research momentum. This heightened research interest is also rooted in the evidence that teachers' beliefs become central importance for understanding and improving educational processes and teaching practices (Barrot, 2015; Kane, Sandretto, \& Heath, 2002). They are closely linked to teachers' strategies for coping with challenges in their daily professional activities, shape students' learning environment and influence students' motivation and achievement (Wilkins, 2008). They have a strong impact on classroom practices (Barrot, 2015; Basturkmen, 2012; Farrell \& Bennis, 2013; Kuzborska, 2011) and influence how the teachers facilitate the interaction between learner, teacher, and subject matter in a particular classroom context with particular resources (Breen, Hird, Milton, Oliver, and Thwaite, 2001).

Other research evidence is also reported that teachers' beliefs and practices do not always integrate basic principles of teaching reading (Barrot, 2015; Nazari, 2014). They posit that teachers' theoretically based beliefs are not related to their practices in teaching reading. There is inconsistency between the teachers' beliefs and their classroom practices due to a complex interaction. In other words, teachers apply practical knowledge (obtained from their 
actual experience) and not theoretical knowledge (theory and principles of teaching reading comprehension) when they teach reading in the classroom (Barrot, 2015). It is an existing gap between the teaching principles in reading comprehension and teaching beliefs of EFL teachers; and this gap becomes more complex when teachers apply their beliefs in reading classroom.

One example of principles that can be applied in teaching reading is a socio-cognitive perspective. However, not many studies have been carried out to investigate whether the teachers are aware to apply the principles of sociocognitive in teaching reading. This study, therefore, would like to examine the teachers' beliefs and practices in teaching reading viewed from socio-cognitive perspective.

\section{Teacher Belief}

Teacher belief plays a dominant role in teacher professional development and teaching practice. It refers to an unobservable cognitive dimension of teaching including what the teachers know, believe, and think (Borg, 2003). This definition is based on the assumption that teachers are active decision-makers who make choice as to what and how of teaching based on their network of knowledge, beliefs, and thoughts (Barrot, 2014, Borg, 2003). Vygotsky (1978) also added a social aspect to teacher beliefs by including the interconnected inferences in how a person constructs themselves in relation to the world. From his own belief constructs, a person will base his actions. In this context, belief means a conception, world view, and mental model that shape learning and teaching practices (Emest, 1989; Nazari, 2014).

There have been many studies conducted on the relationship between the teachers' beliefs and practices in teaching reading. An integrated teaching study was conducted by Barrot (2015) who examined the teaching beliefs and practices of experienced ESL teacher from a socio-cognitive-transformative perspective. Using semi-structured interview, the five ESL teachers were interviewed focusing on their beliefs and practices as regards second integrated language teaching involving reading, listening, speaking, writing, and grammar. The findings revealed that there were consistencies between their beliefs and practices and some divergence were also observed.

Unlike the first studies, Kuzborska (2011) conducted a study to explore the theoretical beliefs about reading instruction and the instructional practices of a total of eight Lithuanian English for Academic Purposes (EAP) teachers who taught reading to a group of advanced EAP learners. Data were collected through video-recorded, semi-structured interviews, classroom observations, and document analysis. Despite the discrepancy, the findings of the study showed correspondence between the theoretical beliefs and instructional practices

In a more recent study, Karimi, Abdullahi, and Khales Haghighi (2014) also investigated the differences between teachers' beliefs in reading instruction and reading instructional practices between two groups of high-efficacy and low-efficacy EFL teachers. Moreover, the researchers explored the degree to which the teachers' classroom-based reading instructional practices correlated with their self-reported theoretical orientations to reading instruction. The findings of the study confirmed that there was a little alignment between teachers' beliefs and their actual instructional practices.

In addition, Nazari (2014) conducted a study on teachers' opinions and practices regarding reading comprehension classes of 21 male and female teachers at Shiraz Azad University and the Iran Language Institute (ILI). It was found that there was a consistency between teachers' beliefs about reading strategies and their classroom practices. It was also found out that, in spite of being generally aligned, there was some contradictory evidence regarding teachers' stated beliefs and their actual classroom practices.

\section{Socio-cognitive Perspective in Reading Comprehension}

A socio-cognitive perspective is a perspective stating that learners' cognitive development is achieved through mediation of more knowledgeable others (MKO) in classroom social interaction. The mediation includes persons (peer, teacher, expert), artifacts (course book, material, signs), and tools (technology, computer, others) which function to facilitate the students' learning (Vygotsky, 1978). They also served as scaffolds who facilitate students' learning process in their zone of proximal development (ZPD) (Lantolf, 2015; Ormrod, 2008; Schunk, 2012; Swain M, Kinnear P, and Steinman L, 2015; Vygotsky, 1978). The theory strongly posits that cognitive development will be supported well through mediation, scaffoldings, ZPD and cognitive apprenticeship (Daftarifard \& Birjandi, 2017; Hill, 2012; Mayer, 2014; Ormrod, 2008; Sadeghi, Afghari \& Zarei, 2016; Schunk, 2012). 
Applied in the teaching of reading, socio-cognitive theory of Vygotsky is relevant to the essence of reading comprehension. It aims at facilitating learners improve their strategic reading skills and help them take on more responsibility of their reading activities (Duffy, 1991; Vygotsky, 1978). The theoretical framework of sociocognitive reading comprehension is based on the socio-cognitive theory which emphasizes on the crucial role of social interaction in cognitive development of reading comprehension. This perspective views that reading is interactive and both cognitive and social aspects influence readers' understanding on text to construct meaning (Snow, 2002; Vygotsky, 1978)). This social occurrence is peer-mediated instructions and can be fostered when teaching is focused on the learner's zone of proximal development (ZPD). This zone means the area between the level at which the students is currently achieving and the level at which the student can achieve if there is assistance (scaffolding) from a more knowledgeable person or a more sophisticated other.

Based on the description, there are four main concepts of socio-cognitive which are applied in teaching reading comprehension, namely mediation, ZPD, cognitive apprenticeship and scaffolding. They are relevant with the concept of reading formulating that students' comprehension is influenced by the factors of reader, text, activity, and sociocultural context in the environment (McLaughlin \& Overturf, 2013; Neuman \& Gambrell, 2013; Tantillo, 2013; Vacca, 2015). The relevance of socio-cognitive theory in reading comprehension concept is explained as follows.

First, socio-cognitive theory believes that human mind is mediated. It means that there is no knowledge and cognitive development obtained directly but through mediation (Daftarifard dan Birjandi, 2017; Vygotsky, 1978). In fact, the students can obtain the knowledge directly but it cannot yet function optimally, therefore, mediator (MKO, peers, artifacts, tools) within social interaction is needed to form the knowledge more matured (Al-Faki \& Siddiek, 2013; Anderson, 2014; Ehri, 2014). The main task of MKO is to facilitate the students to find their own inquiry.

Second, the theory believes that individuals' potency can develop optimally within his ZPD. The development grows through cognitive mediator and scaffolding in social interaction (Colter \& Ulatowski, 2017). To attain the better purpose, the students must get used to doing challenging tasks so that they can focus their attention to finish the tasks easily (Vygotsky, 1978). In this context, learning resources derive from outsider and may vary depending on teachers' and students' creativity in finding them. In reading instruction, students' ZPD is developed through challenging tasks and texts in reading comprehension activity (Lee \& Mallinder, 2017; Hwang, et. al, 2015). These are intended to increase the level of students' understanding through modeling text and its exercises (Ogle, Blachowicz, \& Fisher, 2015). ZPD is also developed through Islamic tasks-oriented reading and evaluation intended to know how far the students comprehend text. The task-oriented reading aimed at facilitating students to become successful readers (Anderson, 2014; Waring \& McLean, 2015).

Third, the theory holds that scaffolding is an effective way to help students develop their competence during social interaction. In this research, scaffolding refers to a teaching tool that serves as a support to develop students' reading competence (Amerian \& Mehri, 2014; Lantolf, Thorne \& Poehner, 2015). The forms of assistance may vary depending on the problem that students encounter. One of examples is reading strategy (Anderson, 2014). The scaffolding can be stratified and called multi-layered-scaffoldings which function to scaffold students' reading comprehension to be strategic readers (autonomous readers).

Fourth, the theory claims that cognitive apprenticeship concept can stimulate students' cognitive development in their ZPD (Lee, 2017). In reading context, cognitive apprenticeship can be applied in every types of activity in the three phases of reading activities. The forms of task-oriented readings in cognitive apprenticeship include, mentoring, scaffolding, and self-reflection to evaluate the progress (Widodo, 2016).

Referring to the explanation and brief review of previous researches, there was no study conducted to examine the teachers' beliefs and practices in teaching reading viewed from a socio-cognitive perspective. This study, therefore, intended to address the following research questions.

1. What are the teachers' beliefs in teaching reading viewed from a socio-cognitive perspective?

2. What are the teachers' practices in teaching reading viewed from a socio-cognitive perspective?

\section{Research Methods:-}

This qualitative research employed a case study exploring primarily upon the teachers' beliefs and practices in teaching reading viewed from a socio-cognitive perspective. The method was chosen because it best facilitates the 
construction of detailed, in-depth understanding of what is to be studied, and can engage with the complexity of real-life events (Stake, 1995; Yin, 1994).

This study was conducted at State Islamic Senior High School (Madrasah Aliyah) in Central Java, Indonesia. Three experienced EFL teachers from three schools were selected purposefully based on the academic and teaching background as main criteria. They should at least have ten years of EFL teaching experience, a master's degree (MA) in English Education, and relevant experience in language teaching workshop. The profile of the three teachers is presented in Table 1.

Table 1:-The Profile of EFL Teachers

\begin{tabular}{|c|c|c|c|}
\hline & $\mathrm{T} 1$ & $\mathrm{~T} 2$ & $\mathrm{~T} 4$ \\
\hline Academic degree & MA & MA & MA \\
\hline Expertise & $\begin{array}{ll}\text { English } & \text { Language } \\
\text { Education } & \end{array}$ & $\begin{array}{ll}\text { English } & \text { Language } \\
\text { Education } & \end{array}$ & $\begin{array}{l}\text { English Language } \\
\text { Education }\end{array}$ \\
\hline $\begin{array}{l}\text { Years of teaching } \\
\text { experience }\end{array}$ & 24 & 24 & 15 \\
\hline Experience & $\begin{array}{l}\text { Teaching } \\
\text { Development }\end{array}$ & $\begin{array}{l}\text { Teaching } \\
\text { Development }\end{array}$ & Teaching Methodology \\
\hline Gender & Female & Female & Male \\
\hline
\end{tabular}

Table 1 showed that three teachers have already got a master's degree in English Language Education (MA). They have been teaching English for more than 14 years. Three teachers have experienced in developing teaching materials and another has experienced in teaching methodology.

The source of the data included informants, artifacts, and events. The first referred to the three teachers who were considered to have enough knowledge, beliefs, and practices in teaching reading viewed from a socio-cognitive perspective. They were also considered to be competent in giving detailed information related to the issue. The second referred to the documents used by the teachers in teaching. The last constituted the teachers' practices in teaching reading in the classroom relevant to their beliefs The techniques of collecting data in this study included in depth-interview, classroom observation, and document analysis. The collected data were analyzed using constant comparative method, comprising four steps: (1) comparing incidents applicable to each category, (2) integrating categories and their properties, (3) delimiting the theory, and (4) writing the theory (Babbie, 2001).

This study used an interview as a technique to explore the teachers' beliefs and observation was used to confirm their practices in teaching reading viewed from a socio-cognitive perspective. The instrument consisted of two main parts of questions focusing on the teachers' academic and teaching background and their teaching beliefs and practices in teaching reading viewed from a socio-cognitive perspective. The first part consisted of five questions and the second part consisted of six questions related to the teaching of reading viewed from sosio-cognitive perspectives.

Before the formal interview was done, the interview guide was validated by three experts relevant to the principles of teaching reading viewed from a socio-cognitive perspective. They suggested that the questions were briefly and semi-structured formatted to enhance the flexibility in communication both for interviewer and interviewee (Nunan, 1991).

The three participants were interviewed individually based on the interview guide and it took about one hour each. The overall interview guide was firstly distributed to the interviewees to learn since by knowing the questions in advance the interviewees could get better understanding on what essential material a question addressed so that they were able to give information needed more accurately. The process of interview was video-recorded to guarantee the actual information given by the interviewees. At the end, the video-recorded data were transcribed and decoded for analysis. Each response was coded and placed under the predetermined categories and it was possible that one response could be placed in some related topics (Janzen, 2007). Getting the results of interview, classroom observation was also conducted excessively to see the evidence of the three teachers' classroom practices. 


\section{Results and Discussion:-}

Teachers' Beliefs in Teaching Reading viewed from Socio-cognitive Perspective.

The three experienced EFL teachers were interviewed face to face based on the interview guide. The teachers' responses were video-recorded and extracted into the result using content analysis. The results of the interview were summarized and presented in Table 2.

Table 2:-Teachers' Beliefs in Teaching Reading Viewed from Socio-cognitive Perspective

\begin{tabular}{|l|l|l|l|l|}
\hline No & Principles & \multicolumn{1}{|c|}{ Teacher 1 } & \multicolumn{1}{c|}{ Teacher 2 } & \multicolumn{1}{c|}{ Teacher 3 } \\
\hline 1 & $\begin{array}{l}\text { The importance } \\
\text { of reading }\end{array}$ & $\begin{array}{l}\text { Reading is very important. } \\
\text { It determines the success in } \\
\text { academic life and career. }\end{array}$ & $\begin{array}{l}\text { Reading is very } \\
\text { important. It becomes the } \\
\text { main material in national } \\
\text { examination. }\end{array}$ & $\begin{array}{l}\text { Reading is very important } \\
\text { because it is a basic skill in } \\
\text { education. It is door key of } \\
\text { science. }\end{array}$ \\
\hline 2 & $\begin{array}{l}\text { Purpose of } \\
\text { teaching reading }\end{array}$ & $\begin{array}{l}\text { To facilitate students } \\
\text { understand the meaning of } \\
\text { the texts easily. }\end{array}$ & $\begin{array}{l}\text { To help students } \\
\text { comprehend the meaning } \\
\text { from texts. }\end{array}$ & $\begin{array}{l}\text { To help students understand } \\
\text { the content of what they } \\
\text { read }\end{array}$ \\
\hline 3 & $\begin{array}{l}\text { Mediated } \\
\text { learning }\end{array}$ & $\begin{array}{l}\text { The learning is mediated } \\
\text { through course books, peers } \\
\text { and teacher }\end{array}$ & $\begin{array}{l}\text { The learning is mediated } \\
\text { through video, and } \\
\text { teachers }\end{array}$ & $\begin{array}{l}\text { The learning is mediated } \\
\text { through course books and } \\
\text { teachers }\end{array}$ \\
\hline 4 & Scaffoldings & Reading strategies & Translation & Diagram \\
\hline 5 & $\begin{array}{l}\text { Cognitive } \\
\text { Apprenticeship }\end{array}$ & Modeling & Modeling & Modeling \\
\hline 6 & ZPD & Problem solving & Homework & Homework \\
\hline
\end{tabular}

Theoretically, the three teachers have not been familiar with the term socio-cognitive perspective and the four basic aspects applied in the teaching reading. P (female teacher 1) said,

"Actually I do not know the theory of socio-cognitive. Reading the interview guide, I become confused and ask myself of what to say in teaching reading. I do not understand the terms of mediated learning, scaffolding, cognitive apprenticeship and ZPD. I think my friend do not know either. I just read them for the first time. When reading over and over, I relate the terms to my experience in teaching reading and finally I can guess what the core is".

After being given clear explanation of each question, they become aware that they know the theory of sociocognitive though just the terms. The followings are explanations of teachers' beliefs in teaching reading viewed from socio-cognitive perspective as presented in the summary in Table 2.

First, the three experienced EFL teachers believed that reading is very important to teach. Based on the reasons given, it can be said that reading constituted a basic skill in education, determiner of one's success in career and academic life. The better the students have reading skills, the better the success the students will get. In contrast, if the students have low reading skills it will make them fail in getting ideas, understanding the meaning of texts and bring about a failure (Alharbi, 2015).

Secondly, in spite of three different statement of teaching objectives, the three teachers basically agreed that they teach reading to facilitate their students understand what they read easily. They wanted to help their students comprehend the content of what they read without any difficulty. In other word, they are supposed to be strategic readers. It is in line with the basic principles in teaching reading that teaching reading means to facilitate students to be strategic readers through a complex engagement with various texts (Anderson, 2014).

Thirdly, all teachers believed that human mind is mediated. The mediation took the forms of course books and videos-based materials. Both of them are teaching material. They said that course books are main mediation that they use in teaching reading. They become the main source for classroom activities. This idea is supported by the results of study stating that course books serves as main component in teaching learning process and have many advantages, namely as (1) syllabus and learning framework for teachers and students, (2) standardization of teaching, (3) an effective and efficient resources, (4) the media for quality maintenance, and (5) an interesting and motivating learning resources (Aydin, 2012; Charalombous, 2011; Srakang \& Jansem, 2013). Despite the course books and video, mediation may take the forms of objects, artifacts, tools, MKO (teachers and peers), and learning community. 
Fourth, the three teachers believed that students' comprehension was enhanced by multi-layered scaffoldings. They mentioned that they used reading strategies, translation, and diagram as the forms of scaffolding to facilitate students understand texts easily. This concept is in line with what is suggested by Vygotsky (1978) that scaffolding is a form of assistance given by an adult (teachers and peers) to students to finish their task in their ZPD. The assistance includes instruction, all types of strategy, media, concept maps, tools, technology, and explanation.

Fifth, the three teachers also believed that students' comprehension could be engaged through some types of cognitive apprenticeship. The form of cognitive apprenticeship they applied in teaching reading was modeling of text presented in the course books. They considered that modeling of text can assist students understand texts easily. In teaching reading, the modeling of text presented in the course books is included in the form of cognitive apprenticeship or scaffolding. That is called multi-layered scaffolding. In this context, modeling meant the example or model given by the teachers to be imitated in actions. In addition, coaching, mentoring, reflection, articulation are different forms of the aspect (Lee, 2017).

Sixth, the three teachers stated that students' competence could be fostered optimally within their ZPD through the activity of problem solving and giving homework. They did not think the theory of ZPD in socio-cognitive theory. They only thought of the way in developing students' competence for critical thinking. It seemed that the teachers answered the questions by guessing only because they needed a long pause to think. In the theory, Vygotsky believed that when a student is at the ZPD for a particular task, providing the appropriate assistance (scaffolding) will give the student enough of a "boost" to achieve the task. Once the student, with the benefit of scaffolding, masters the task, the scaffolding can then be removed and the student will then be able to complete the task again on his own.

\section{Teachers' Practices in Teaching Reading viewed from a Socio-cognitive Perspective}

Classroom observation of the three experienced teachers was done to make sure whether they really practiced their beliefs in teaching reading viewed from socio-cognitive perspective. The results of the classroom observation were summarized and presented in Table 3.

Table 3:-Teachers' Practices in Teaching Reading Viewed from Socio-cognitive Perspective

\begin{tabular}{|c|c|c|c|c|}
\hline \multirow[t]{2}{*}{ No } & \multirow[t]{2}{*}{ Principles } & \multicolumn{3}{|c|}{ Evidence in Classroom Practice } \\
\hline & & Teacher 1 & Teacher 2 & Teacher 3 \\
\hline 1 & $\begin{array}{l}\text { The importance } \\
\text { of reading }\end{array}$ & $\begin{array}{l}\text { Stating the importance of } \\
\text { reading to students both } \\
\text { written in the lesson plans } \\
\text { and in classroom practice. }\end{array}$ & $\begin{array}{l}\text { Stating the importance of } \\
\text { reading to students both } \\
\text { written in the lesson plans } \\
\text { and in classroom practice. }\end{array}$ & $\begin{array}{l}\text { Stating the importance of } \\
\text { reading to students both } \\
\text { written in the lesson plans } \\
\text { and in classroom practice. }\end{array}$ \\
\hline 2 & $\begin{array}{l}\text { Purpose of } \\
\text { teaching } \\
\text { reading }\end{array}$ & $\begin{array}{l}\text { - Stating the purpose of } \\
\text { teaching reading } \\
\text { - Guide students step by } \\
\text { step }\end{array}$ & $\begin{array}{l}\text { - Stating the purpose of } \\
\text { teaching reading } \\
\text { - Asking students to work } \\
\text { in groups }\end{array}$ & $\begin{array}{l}\text { - Stating the purpose of } \\
\text { teaching reading } \\
\text { - Asking students to do the } \\
\text { task individually }\end{array}$ \\
\hline 3 & $\begin{array}{l}\text { Mediated } \\
\text { learning }\end{array}$ & $\begin{array}{l}\text { - Using course book } \\
\text { - Explaining and helping } \\
\text { students learn. } \\
\text { - Making group works } \\
\end{array}$ & $\begin{array}{l}\text { - Using video-based } \\
\text { materials } \\
\text { - Help students to translate } \\
\text { the sentences }\end{array}$ & $\begin{array}{l}\text { - Using course book } \\
\text { - Explaining the content of } \\
\text { text by himself }\end{array}$ \\
\hline 4 & Scaffoldings & $\begin{array}{l}\text { - Practicing scanning, } \\
\text { skimming, deducing } \\
\text { meaning from contexts }\end{array}$ & $\begin{array}{l}\text { - Asking students translate } \\
\text { the meaning of text }\end{array}$ & $\begin{array}{l}\text { - Asking students to fill in } \\
\text { the diagram presented in } \\
\text { the course book }\end{array}$ \\
\hline 5 & $\begin{array}{l}\text { Cognitive } \\
\text { Apprenticeship }\end{array}$ & $\begin{array}{l}\text { Giving the model to be } \\
\text { imitated in doing tasks }\end{array}$ & $\begin{array}{l}\text { Giving the model of } \\
\text { descriptive text }\end{array}$ & $\begin{array}{l}\text { Giving the model of song } \\
\text { presented in the course book }\end{array}$ \\
\hline 6 & $\mathrm{ZPD}$ & $\begin{array}{l}\text { Small group discussion on } \\
\text { Islamic verse related to the } \\
\text { topic }\end{array}$ & $\begin{array}{l}\text { Giving homework to do at } \\
\text { home }\end{array}$ & $\begin{array}{l}\text { Giving homework to do at } \\
\text { home }\end{array}$ \\
\hline
\end{tabular}

The followings are explanation of teachers' classroom practices as what have been summarized in Table 3 .

Firstly, all the teachers proved that they believed about the importance of reading for the students. At the beginning of the lesson, they stated it to the students and they also stated it written in their lesson plans. By knowing the importance of reading, it is supposed to trigger the students learn better. 
Secondly, the three teachers proved that orally they stated the objective of teaching reading as what they believed. It could be seen from their activities in the beginning of lesson. The first teacher guides the students learn step by step in understanding the text. It seemed that what she did could work well because all students were actively engaging in the activities. The second teacher guides students to work in group of four persons. She asked one of the participants to be the leader to guide the group. Another teacher, however, asked the students to work individually. It is in contrary with principle of socio-cognitive.

Thirdly, all teachers proved that course books become the mediators in teaching reading. The students have course books and video-based materials for classroom reading activities. The first teacher explains the lesson and the way how they learn and understand the lesson through small group discussion. It is supposed to train students solve the problems with their peers. The second and third teachers, however, do not guide the students to learn. Instead of guiding the students, they did the tasks by themselves and the students just write the answers. The students could get nothing in the the lesson.

Fourth, the three teachers proved that they have applied multi-layered scaffoldings in teaching reading. The forms of scaffoldings took different forms of reading strategy. The first teacher seemed to have mastered more strategies that two other ones. The first teacher guided the students using different reading strategies step by step so that students found it easy to do the tasks. One male student said,

"I like using this way. By using scanning I can answer the questions quickly and correctly. By using skimming I can find topic sentence and answer the questions related to it without reading all part of text. By knowing the key words before reading the text, I can understand the content of the text by guessing or deducing meaning from the context. When I practice them repeatedly, they would become habits and, finally skills".

Translation and diagram were different forms of strategies applied by two other teachers. They still did it like conventional methods because those led to teacher-centered learning activity.

Fifth, the teachers applied the concept of cognitive apprenticeship through modeling activity. All teachers took the form of modeling only as it was stated in the course book. Based on the modeling provided, the teachers gave explanation to students to follow their examples. It indicated that the practices reflected the beliefs though just limited to one form.

Sixth, the teachers proved that they applied the concept of ZPD. They helped students at their ZPD by giving them challenging tasks in a small group. They guide the students do discussion on verse related to Islamic History entitled "Muhammad the Messenger". The verse was about the role model and their examples in every aspect of life. Two other teachers applied challenging tasks in the form of homework only taken from the course books. Ironically the homework was not confirmed as to give feedback in the next lesson. It meant that there was difference between beliefs and practices.

\section{Conclusion and Suggestion:- Conclusion}

This case study examined the stated beliefs and classroom practices of three experienced EFL teachers in teaching reading viewed from a socio-cognitive perspective in Indonesia. The findings indicated that the teachers' beliefs were articulated in their classroom practices. On the other hands, there were some practices which were not related to their beliefs and these deviances were considered natural since the teachers did negotiated learning adjusting to the real classroom condition. Similar findings have also been reported by previous studies (Barrot, 2015; Farrell \& Ives, 2015; Richards et al, 2001). Even, experienced teacher may have different practices and beliefs (Barrot, 2015; Breen et al, 2001). Consequently, language teachers need to reflect on beliefs and classroom practices because they exist in a symbiotic relationship in which both shape each other, and are shaped by each other (Walsh, 2006).

\section{Suggestion}

Based on the results of the study, it is recommended that teachers join professional development and develop their understanding or knowledge about language teaching and learning based on on certain perspectives. 


\section{References:-}

1. Al-Faki, I. M., \& Siddiek, A. G. (2013). The role of background knowledge in enhancing reading comprehension. World Journal of English Language, 3(4), 42.

2. Alharbi, M. A. (2015). Reading strategies, learning styles and reading comprehension: A correlation study. Journal of Language Teaching and Research, 6(6), 1257-1268.

3. Amerian, M., \& Mehri, E. (2014). Scaffolding in sociocultural theory: Definition, steps, features, conditions, tools, and effective consideration. Scientific Journal of Review, 3(7), 756-765.

4. Anderson, N. J. (2014). A curricular model for reading: The inclusion of extensive reading. Editorial Review Board, 46(1\&2), 1-9

5. Aydin, S. (2012). A review of research on Facebook as an educational environment. Educational Technology research and development, 60(6), 1093-1106

6. Babbie, Earl, 2004. The Practice of Social Research, United State of America, Maple Vail Book Manufacturing Group, Brown.

7. Barrot, J. S. (2015). A Socio-cognitive-transformative instructional materials design model for second language (L2) pedagogy in the Asia Pacific: Development and validation. The Asia-Pacific Education Researcher, 24(2), 283-297.

8. Basturkmen, H. (2012). Review of research into the correspondence between language teachers' stated beliefs and practices. System, 40, 282-295.

9. Borg, S. (2003). Teacher cognition in grammar teaching: A literature review. Language Awareness, 12(2), 96108.

10. Breen, M.P., Hird, B., Milton, M., Oliver, R., \& Thwaite, A. (2001). Making sense of language teaching: Teachers' principles and classroom practices. Applied Linguistics, 11, 470-501.

11. Charalambous, C. Y., Hill, H. C., \& Ball, D. L. (2011). Prospective teachers' learning to provide instructional explanations: how does it look and what might it take?. Journal of Mathematics Teacher Education, 14(6), 441-463

12. Colter, R., \& Ulatowski, J. (2017). The unexamined student is not worth teaching: preparation, the zone of proximal development, and the Socratic Model of Scaffolded Learning. Educational Philosophy and Theory, 49(14), 1367-1380.

13. Daftarifard, P., \& Birjandi, P. (2017). Impact of Mediation Types on Iranian EFL Learners' Reading Comprehension Strategies. Research in Applied Linguistics, 8(1), 22-45.

14. Ehri, L. C. (2014). Orthographic mapping in the acquisition of sight word reading, spelling memory, and vocabulary learning. Scientific Studies of Reading, 18(1), 5-21.

15. Ernest, P. (1989). The impact of beliefs on the teaching of mathematics. Mathematics teaching: The state of the art, 249, 254.

16. Farrell, T. S., \& Bennis, K. (2013). Reflecting on ESL teacher beliefs and classroom practices: A case study. RELC journal, 44(2), 163-176.

17. Farrell, T. S., \& Ives, J. (2015). Exploring teacher beliefs and classroom practices through reflective practice: A case study. Language Teaching Research, 19(5), 594-610.

18. Harste, J., \& Burke, C. (1977). A new hypothesis for reading teacher research: Both the teaching and learning of reading are theoretically based. In P. D. Pearson \& J. Hansen (Eds.), Reading: Theory and practice: Twentysixth yearbook of the national reading conference (pp. 32-40). Clemson, SC: National Reading Conference.

19. Hill, W. F. (2011). Theories of Learning. Bandung: Nusa Media.

20. Huang, Y. M., \& Liang, T. H. (2015). A technique for tracking the reading rate to identify the e- book reading behaviors and comprehension outcomes of elementary school students. British Journal of Educational Technology, 46(4), 864-876

21. Janzen, J. (2007). Preparing teachers of second language reading. Tesol Quarterly, 41(4), 707-729.

22. Kane, R., Sandretto, S., \& Heath, C. (2002). Telling half the story: A critical review of research on the teaching beliefs and practices of university academics. Review of Educational Research, 72, 177-228.

23. Karimi, M. N., \& Dehghani, A. (2016). EFL teachers' beliefs/practices correspondence in reading instruction: does language teacher education make a difference? International Journal of Pedagogies and Learning, 11(1), $35-48$

24. Khaliliaqdam, S. (2014). ZPD, scaffolding and basic speech development in EFL context. Procedia- Social and Behavioral Sciences, 98, 891-897.

25. KhKuzborska, I. (2011). Links between teachers' beliefs and practices and research on reading. Reading in a Foreign Language, 23, 102-128

26. Lantolf, J. P. (2000). Second language learning as a mediated process. Language teaching, 33(2), 79-96. 
27. Lantolf, J. P., Thorne, S. L., \& Poehner, M. E. (2015). Sociocultural theory and second language development. Theories in second language acquisition: An introduction, 207-226.

28. Lee, H. C. (2017). A Case Study: Reading Strategies Training Scheme in a Hong Kong Primary School. TESOL Journal, 8(1), 190-214.Lee, H. N., \& Mallinder, M. (2017). Role of extensive reading in EFL vocabulary development: Review and recommendation. The English Teacher, 12-19.

29. Mayer, R. E. (2008). Learning and Instruction: Teaching by Creating Cognitive Apprenticeship in Classrooms and Beyond. Second Edition. Merill Pearson Prentice Hall.

30. McLaughlin, M., \& Overturf, B. (2013). The Common Core: Teaching Students in Grades 6-12 to Meet the Reading Standards. Newark. DE: International Reading Association.

31. Nazari, A., \& Bagheri, M. S. Teachers' Opinions and Practices Regarding Reading Comprehension Classes.

32. Nunan, D. 1991. Language Teaching Methodology: A Textbook for Teachers. Hertfordshire: Prentice Hall International (UK) Ltd.

33. Nuttall, C. (2006). Teaching reading skills in a foreign language (3rded.). Oxford, UK: MacMillan Education.

34. Ogle, D., Blachowicz, C., \& Fisher, P. (2015). Academic Vocabulary in Middle and High School: Effective Practices Across the Disciplines. Guilford Publications.

35. Ormrod, J. E. (2008). Developmental perspectives. Human learning, 308-349.

36. Richards, J. C. (2001). Curriculum Development in Language Teaching. Ernst Klett Sprachen.

37. Richardson, V., Anders, P., Tidwell, D., \& Lloyd, C. (1991).The Relationship Between Teachers' Beliefs and Practices in Reading Comprehension Instruction. American Educational Research Journal, 28(3), 559-586.

38. Schunk, D. H., \& Zimmerman, B. J. (Eds.). (2012). Motivation and self-regulated learning: Theory, research, and applications. Routledge.

39. Snow, C. (2002). Reading for understanding: Toward an R\&D program in reading comprehension. Rand Corporation.

40. Srakang, L., \& Jansem, A. (2013). A Study of Teachers' Perceptions toward Using English Textbooks: A Case Study of 10th Grade English Teachers in Maha Sarakham Province (Doctoral dissertation, Srinakharinwirot University).

41. Stake, R.E. (1995). The art of case study research. Thousand Oaks, CA: Sage.

42. Swain, M., Kinnear, P. and Steinman, L. (2015). Sociocultural theory in second language education: An introduction through narratives (2nd edition). Bristol: Multilingual Matters

43. Tantillo, S. (2013). The Literacy Cookbook. San Francisco: Jossey-Bass a Wiley Imprint.

44. Vacca in Wineburg, S., \& Reisman, A. (2015). Disciplinary Literacy in History. Journal of Adolescent \& Adult Literacy, 58(8), 636-639

45. Vygotsky, L. S. (1978). Mind in society: The Development of Higher Psychological Functions. Harvard, Cambridge, MA

46. Walsh, S. (2006). Investigating Classroom Discourse. London: Routledge.

47. Waring, R., \& McLean, S. (2015). Exploration of the Core and Variable Dimensions of Extensive Reading Research and Pedagogy. Reading in a Foreign Language, 27(1), 160-167.

48. Widodo, H. P. (2016). Engaging Students in Literature Circles: Vocational English Reading Programs. The Asia-Pacific Education Researcher, 25(2), 347-359.

49. Wilkins, J. L. (2008). The relationship among elementary teachers' content knowledge, attitudes, beliefs, and practices. Journal of Mathematics Teacher Education, 11(2), 139-164.

50. Yin, R.K. (1994). Case study research: Design and methods. 2nd edition. Thousand Oaks, CA: Sage. 